\title{
Implementation of the ISO 50001 standard to sustainable energy and economic saving the industrial sector
}

\author{
Implementación de la Norma ISO 50001 para ahorros sostenibles energéticos y \\ económicos en el sector industrial
}

\author{
G. Valencia-Ochoa ; K. Rodriguez-Rodriguez ; G. Torregroza-Matos ; ; . Acevedo-Penaloza iD \\ ; J. Duarte-Forero
}

\begin{abstract}
Given the growth in energy demand, the limited energy resources, and the high environmental impact of energy generation from fossil fuels, it is vital to find methods to obtain save energy costs in different sectors, such as residential, industrial, transportation sector, and domestic. This paper presents a methodology that allows the implementation of an energy management system following the guidelines of the ISO 50001 standard. A gap analysis was performed to determine the position of the organization with respect to the requirements of the standard, and the next step was the inspection of the plant to find opportunities for improvement that would lead to energy optimization. From the results, six equipment was the cause of the $82 \%$ of the energy consumption in the production process, and some recommendation was proposed with the aim to optimize energy consumption. A methodology is proposed for the standard implementation, which can be implemented by different organizations from different fields to achieve savings in energy costs in the plant. Some relevant actions to improve the energy performance of the plant were proposed, such as the optimization of the compressed air system, the reduction of potential numbers of leakage, and the reduction of the working pressure of the system.
\end{abstract}

Index Terms - energetic analysis; energetic characterization; energy management systems; ISO 50001; saving cost.

Resumen - Dado el crecimiento en la demanda de energía, los recursos energéticos limitados y el alto impacto ambiental de la generación de energía a partir de combustibles fósiles, es vital encontrar métodos para obtener ahorros en los costos de energía en diferentes sectores, como el residencial, el industrial y el transporte. nivel doméstico Este artículo presenta una metodología que permite la implementación de un sistema de gestión de energía siguiendo las pautas de la norma internacional

This manuscript was sent on November 18,2019 and accepted on May 11, 2020. This work was supported by the Universidad del Atlántico.

G. E. Valencia O. is with the Mechanical Engineering Department, Universidad del Atlántico, Carrera 30 Número 8-49, Puerto Colombia, Barranquilla 080007, Colombia, (e-mail: guillermoevalencia@mail.uniatlantico.edu.co)

K. Rodriguez R. is with the energy efficiency research group from the Engineering Faculty, Universidad del Atlántico, Carrera 30 Número 8-49, Puerto Colombia, Barranquilla 080007, Colombia, (e-mail: knrodriguez@mail.uniatlantico.edu.co)

G. Torregroza $M$. is with the energy efficiency research group from the Engineering Faculty, Universidad del Atlántico, Carrera 30 Número 8-49,
ISO 50001. Donde, en primer lugar, se realizó un análisis de brechas para determinar la posición de la organización con respecto a los requisitos que se encuentran en la norma, el siguiente paso fue la inspección de la planta para encontrar oportunidades de mejora que condujeran a la optimización energética. De los resultados, seis equipos fueron la causa del $82 \%$ del consumo de energía en el proceso de producción, y se propusieron algunas recomendaciones con el objetivo de optimizar el consumo de energía. Se propone una metodología para la implementación estándar, que puede ser implementada por diferentes organizaciones de diferentes campos para lograr ahorros en los costos de energía en la planta. Se propusieron algunas acciones relevantes para mejorar el rendimiento energético de la planta, como la optimización del sistema de aire comprimido, la reducción del número potencial de fugas y la reducción de la presión de trabajo del sistema.

Palabras claves - Ahorro de costos; Análisis energético; Caracterización energética; ISO 50001; Sistemas de gestión energética.

\section{INTRODUCTION}

$\mathrm{T}$ The energy consumption in the industrial and commercial sector comprising $40 \%$ of global emissions of greenhouse gases, given that ISO 5000 provides a framework for constant improvement in pursuit of the reduction of energy consumption, is an ideal measure to give solution to this problem, while it is true that this standard is effective in reducing energy costs, it is not effective in reducing greenhouse gas emissions or reducing environmental impact [1]-[3]. The efficient management of energy is an alternative that helps minimize the costs generated during production, so they have

Puerto Colombia, Barranquilla 080007, Colombia, (e-mail: gtorregroza@mail.uniatlantico.edu.co)

C. H. Acevedo P. is with the Mechanical Engineering Department, Universidad Francisco de Paula Santander, Avenida Gran Colombia No. 12E96, Cúcuta 540003, Colombia, (email: carloshumbertoap@ufps.edu.co)

J.Duarte F. is with the Mechanical Engineering Department, Universidad del Atlántico, Carrera 30 Número 8-49, Puerto Colombia, Barranquilla 080007, Colombia, (e-mail: jorgeduarte@mail.uniatlantico.edu.co) 
carried out various studies to analyze the impacts of renewable energy resources as an alternative to mitigate energy cost to meet energy demand [4]-[6].

Industries demand large amounts of energy, so they can keep all their equipment running to generate goods constantly during the day [7], Therefore, energy represents a fundamental part of the functioning of companies. Thus, to achieve efficient use of energy, companies must make changes in their organizational structure, in the way they carry out their planning and in the decision making the process [8]-[10].

Lira et al.[11] characterized the process of diffusion of the ISO 50001 standard around the world, and the main factors that determine the adoption of this system in different regions of the planet. They used multiple regression models for the number of certificates and environmental indicators, social, economic, climate change and energy of mining, from these data it could be observed that Europe has the highest number of certificates in ISO 50001, Asia has the highest growth rate.

In addition, Pelser et al. [12], uses a monitoring system in the electrical system of a plant, the system consists of an automated performance reporting system, the system acquires data from various sources, thus analyzing which components consume more energy, this system was implemented in a plant in South Africa, where the total energy cost was reduced by $25 \%$, which suggests the effectiveness of the implementation of ISO 50001 and the benefits it brings on the profits of the organization with a minimum investment.

The responsibility for the implementation of an energy standard does not only depend on the industry, but the active participation of the government is also necessary, and in the energy policies, it implements in order to encourage corporate social responsibility [13].

For the proper implementation of this standard, it is necessary to research new methods that allow industries to reduce their production costs, without compromising the quality or quantity of such products, so that this type of research has diversified today, given the critical state in which the planet earth finds itself due to the constant energy demand that has been affected not only by industrial growth but also by the exponential growth of the world population, taking this into account various authors have focused on finding new mechanisms to mitigate to large extent effects that affect to a lesser or greater extent the environment [14]-[18].

The main contribution of this article is the realization of an energetic analysis for an industrial production plant in order to implement an energetic management system (EMS) to optimize the production process based on the proposed performance indicator energetically.

\section{METHODOLOGY}

For the development of this article, a company was selected, which following the guidelines of ISO 50001, made a diagnosis of its energy expenditure and thus draw up an action plan for improving energy use. ISO 50001 was born out of the industry's need to provide an effective response to climate change.

\section{A. Energy management systems}

The steps used in the study were based on previous research, since the certification of ISO 50001, has begun a phase of application around the world, this in order to allow the various organizations to establish an energy strategy to improve energy efficiencies of processes that have hight energetic consumption. The standard suggests a model based on four-steps: the energy policy proposed, the energy planning step, and the implementation and verification step, by mean of a continuous cycle of improvement, where the energy planning aim the improvement of energy performance indicators

\section{B. Energetic Analysis}

The energy analysis was carried out in 3 stages. The first stage consists of the energy review; an awareness was made to the top management of the company in order to understand the benefits of implementing an EMS. Subsequently, visits were made to the facilities in order to identify the energetic-productive structure and capacities of the organization for the implementation of the system.

As part of the diagnosis, the company provided the necessary information to define the scope, such as daily electricity consumption reports, daily production reports for the last twelve months, information on the consumption of other significant primary energy of the organization in the last twelve months and the census of the load of the equipment used in the productive areas and industrial services. In this way, the limits in terms of the energy system, processes, and equipment were defined. The second stage consists of energy characterization, where the main objective is to generate strategic guidelines for the implementation of the EMS in the organization.

This identifies the current state of the company in terms of energy use and characterization tools are applied to determine potential energy savings; the steps applied were the following:

1. Energy matrix, where energy expenditures are quantitatively compared, is carried out in energy units and monetary units.

2. Census of load, the inventory is made by energy type of all the energy-consuming equipment in the different production areas, specific measures are taken for the consumption of each equipment, if these specific measures are not available, they are characterized using the power consumption of the equipment and the average work regime.

3. Analysis of energy demand and production, a graph of energy consumption as a function of time is made to know the behavior of energy demand by energy type at the level of the whole system and the specific areas that have meters.

4. Graphical limits of control, where an upper and lower limit of energy consumption is established in order to detect anomalies in some phase of the process.

5. Baseline data are collected on energy consumption and associated products for the same period of time selected. 
This allows identifying the behavior of the plant in relation to the energy consumption and production level.

6. The target line, is constructed by performing a linear regression with the production and consumption data that is below the baseline, this is done after having obtained the graph of energy vs. production, allows to determine the optimal point of production, where energy consumption is minimal.

7. Diagram consumption-production index, is made after obtaining the graph Energy vs. Production, is very useful to establish EMS and standardize processes concerning energy efficiency, helps establish goals in consumption indexes based on a production planned by market conditions and to determine factors that influence the variations of the index of consumption of the organization.

8. Graph CUSUM and efficiency index base 100, in this stage an energy-productive diagram is made from which a flow diagram of the main production processes of the organization is made, which indicates the stage of the process, the productivity of the block, type of amount of energy entering and leaving each block and the products generated. This in order to identify the final products or byproducts of the productive process and the energy expenses that these entail during the formation process.

9. After the characterization and analysis of this, the areas with significant use of energy are identified and the USE equipment to which an action plan will be designed in order to reduce energy consumption, this action plan is part of the third stage, which consists of the development and implementation of this action plan. In this, the modifications and suggested actions for the closing of gaps against the ISO 50001 standard were reflected. Table I shows the template for the action plan, as well as the corresponding description of each item.

TABLE I

ACTION PLAN TEMPLATE

\begin{tabular}{|c|c|c|c|}
\hline $\begin{array}{l}\text { Specific } \\
\text { require } \\
\text { ment }\end{array}$ & $\begin{array}{l}\text { Modifications and } \\
\text { Suggested Actions }\end{array}$ & $\begin{array}{l}\text { Observation } \\
\mathrm{s}\end{array}$ & Responsible \\
\hline $\begin{array}{l}\text { Gap } \\
\text { analysis } \\
\text { requirem } \\
\text { ents not } \\
\text { met by } \\
\text { the } \\
\text { organizat } \\
\text { ion. }\end{array}$ & $\begin{array}{l}\text { Suggested actions for } \\
\text { agreement with the } \\
\text { requirements. These } \\
\text { actions are numbered, } \\
\text { and if the requirement is } \\
\text { met with a previous } \\
\text { action, reference it. }\end{array}$ & $\begin{array}{l}\text { Additional } \\
\text { recommendat } \\
\text { ions are made } \\
\text { for } \\
\text { compliance } \\
\text { with the } \\
\text { requirements. }\end{array}$ & $\begin{array}{l}\text { For each } \\
\text { requirement, } \\
\text { a person } \\
\text { responsible } \\
\text { for the } \\
\text { organization } \\
\text { al structure } \\
\text { of the } \\
\text { organization } \\
\text { is assigned. }\end{array}$ \\
\hline
\end{tabular}

As a complement to the previous stages, and with the purpose of continuous improvement of the system, a monitoring, and control of indicators is carried out, after the implementation of the action plan, the energy indicators are recalculated after the development of the improvement actions that were proposed, in order to evaluate the results obtained with the implementation of the system, a follow-up is carried out to the implementation, with periodic visits to the plant and verifying that the proposed measures are carried out. Finally, the results obtained are socialized, with the indicators obtained after the revision of the system with the proposed improvements, seeking that all organizational levels that were part of the process have knowledge of the results obtained.

\section{RESULTS AND DISCUSSION}

\section{A. Stage 1-Strategic review}

During the energy review, the company's current energy status is identified and obtained in meetings with the administration and workers, where the necessary information for diagnosis and characterization was requested. At this stage, senior management was made aware of the benefits and scope of the implementation of the energy management system in the facilities, in addition, a joint diagnosis was made among the energy managers, where a census was made of the load of the equipment and areas that consume energy within the plant, which is presented in the energy characterization part.

Following the established guidelines for the implementation of an energy management system, it was necessary to perform a technological characterization that lies in making a series of questions to fill out the forms for subsequent implementation.

Additionally, the way in which the knowledge is acquired, and its development is also evaluated, the company obtained a rating of $74.07 \%$ which implies that it has the required potential for the EMS application under the ISO 50001 standards. In addition, a gap analysis was carried out, useful because it helps to compare the state and real performance of the organization and establish that criteria are not being met. Table II shows the results achieved from the gap analysis:

TABLE II

GAP ANALYSIS RESULT

\begin{tabular}{cc}
\hline \hline Documentary requirement & fulfillment \\
\hline General requirements & $50 \%$ \\
Management responsibility & $0 \%$ \\
Energetic policy & $0 \%$ \\
Energy planning & $32 \%$ \\
General & $29 \%$ \\
Baseline & $38 \%$ \\
IDE & $0 \%$ \\
Objectives, energy goals, and action plans & $42 \%$ \\
Implementation and operation & $16 \%$ \\
Requirements per area & $20 \%$ \\
Document's control & $100 \%$ \\
Verification & $0 \%$ \\
General score & $21.28 \%$ \\
\hline \hline
\end{tabular}

A skills assessment was carried out to calculate the skills that the corporation has for the application of an EMS, containing a rating of 1 to 5. The results are presented in Table III and Fig. 1.

\section{TABLE III}




\section{SCALE OF DIAGNOSTIC ASSESSMENT OF CAPABILITIES}

\begin{tabular}{cl}
\hline \hline Score & \multicolumn{1}{c}{ Description } \\
\hline 1 & $\begin{array}{l}\text { The organization must make changes in this aspect before } \\
\text { initiating an EMS implementation process. }\end{array}$ \\
2 & $\begin{array}{l}\text { The organization has had some initiatives that need to be } \\
\text { formalized in order to be actively integrated into an EMS. }\end{array}$ \\
3 & $\begin{array}{l}\text { The organization has advances that will facilitate the } \\
\text { implementation of an EMS under the requirements of ISO 50001, }\end{array}$ \\
4 & $\begin{array}{l}\text { The organization has conditions to install an EMS under the } \\
\text { requirements of ISO 50001. }\end{array}$ \\
5 & $\begin{array}{l}\text { The organization has high strengths to implement an EMS and } \\
\text { achieve outstanding results in improving its energy performance. }\end{array}$ \\
\end{tabular}

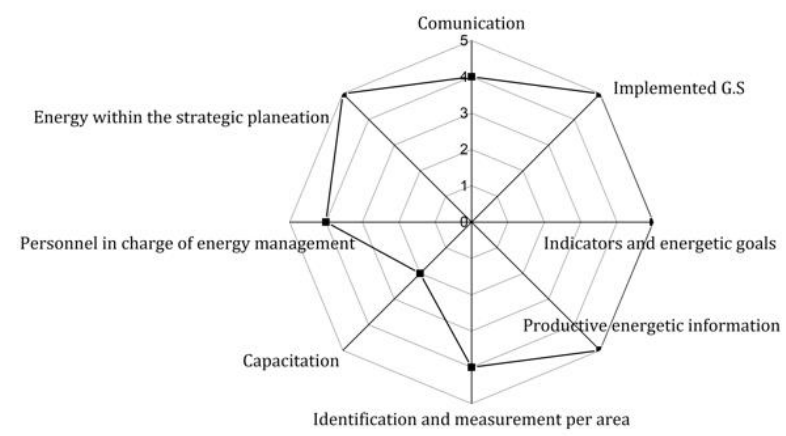

Fig. 1. Diagnosis of the corporation's organizational capacities.

The company is strong in technical aspects, such as the importance of energy aspects in the strategic planning of the corporation, productive energy information, energy indicators, goals, and management systems implemented, where a quality management system is already implemented. In the area of training, more work is required, even though a certain initiative for change has been shown. The fact that the company is strong in the other areas evaluated denotes the commitment it has for the implementation of the EMS within the company and is close to achieving the objectives stipulated.

\section{B. Stage 2- Energetic characterization}

The energetic characterization was carried out in the organization for the qualitative and quantitative analysis of the energy consumption in the period of study, in search of determining the potential of total saving and establishing indicators of control and strategies of operation and maintenance, for this the data of production and of energetic consumption of the studied years were taken into account, besides the equipment used in the production line, it was identified that the totality of energy used is of electric character.

The load profile was carried out with the information supplied by the equipment, details such as the name of the equipment, the nominal power, the hours of use at full load, the energy consumed by the equipment as a result of its operation hours, and the percentage it represents overconsumption of the system are shown in the Pareto diagram. This diagram is used to identify $20 \%$ of the equipment with $80 \%$ total energy consumption on the plant. In the context of the analysis, the equipment and area with the highest energy consumption were considered for prioritizing the energy study and project improvement.

From Fig. 2, it can be observed that about $82 \%$ of monthly consumption is associated with six equipment or machines that will be considered as significant use of energy (USE), so the objective is to reduce the use of these and manage them more efficiently.

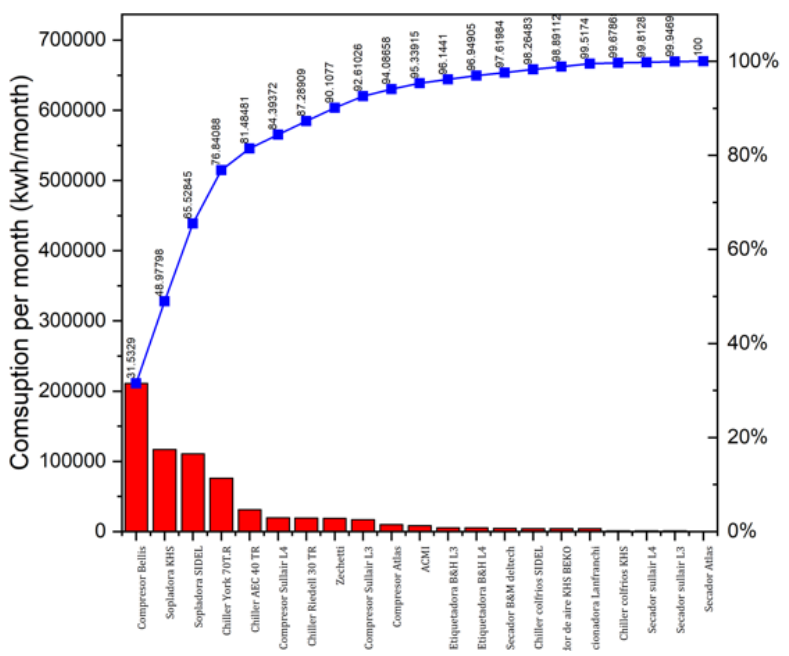

Fig. 2. Pareto diagram per machine.

It can be seen in Fig. 3 that there are three areas that stand out in the energy consumption of the plant, these are compressors, blowing and peripheral equipment that represent about $91 \%$ of total consumption, for which the interest of study will focus on these three areas

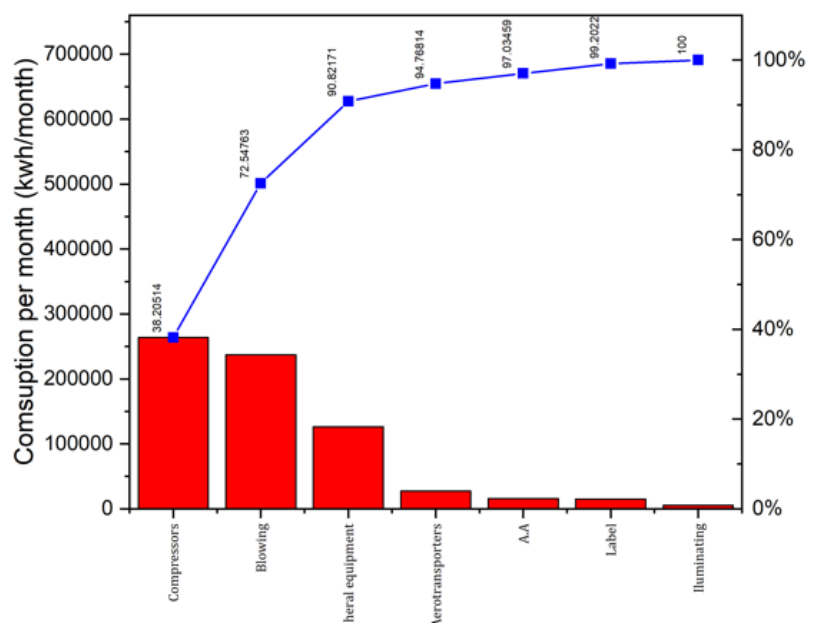

Fig. 3. Pareto diagram by area.

The company provided consumption and production data for the period under analysis, shown in Fig. 4. 


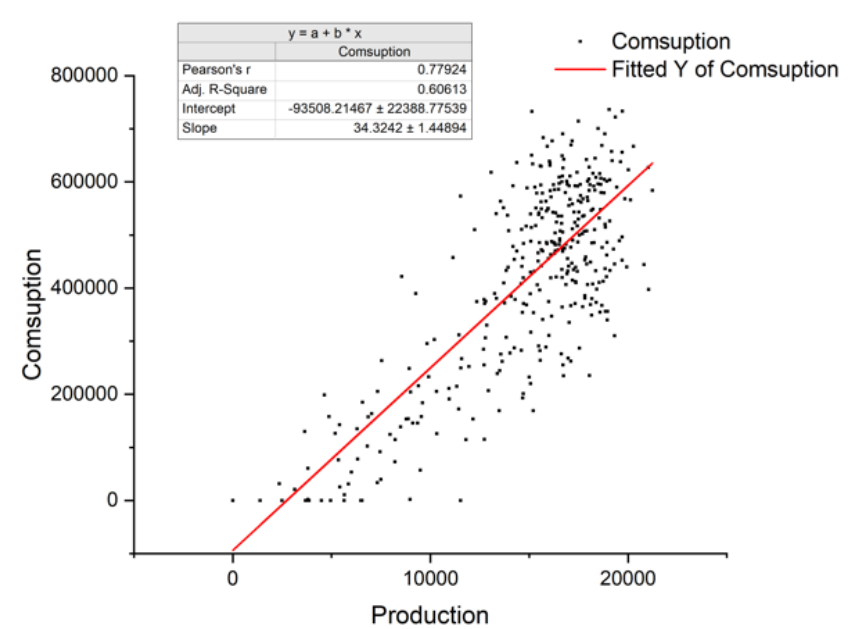

Fig. 4. Consumption vs. production graph.

A correlation was obtained $R^{2}=0.6072$ with a baseline according to (1), as follow:

$$
E_{t}=m \cdot P+E N A P
$$

where $E_{t}$ represents the production, $m$ the slope, $P$ the production, and ENAP the intercept, which is the energy not associated with the production, and its values for the previous graph are presented in (2).

$$
E_{t}=0.0177 \cdot P+7498.2
$$

From the graph, it is notorious that there are visually dispersed data, so an adjustment was made in the baseline graph by filtering data, taking as a reference the theoretical energy consumption calculated with (2) baseline. In the data filtering, an interval of a positive and a negative standard deviation was taken, as seen in (3) and (4).

$$
\begin{aligned}
& \text { Superior limit }=E_{t}+\text { Desv } \\
& \text { Inferior limit }=E_{t}-\text { Desv }
\end{aligned}
$$

The condition Upper Limit> $E_{\text {Real }}>$ Lower Limit was established, the consumption data that meet this condition was considered to create the adjusted baseline, shown in Fig. 5. Its correlation is greater $\mathrm{R}^{2}=0.8376$, and its adjusted baseline is (5).

$$
E_{t}=0.0179 \cdot P+7339.8
$$

The target line is constructed using the actual consumption data below the baseline of electricity consumption, i.e., the data for which $\mathrm{E}_{\mathrm{t}}-\mathrm{E}_{\mathrm{Real}}>0$, and the target line shown in (6).

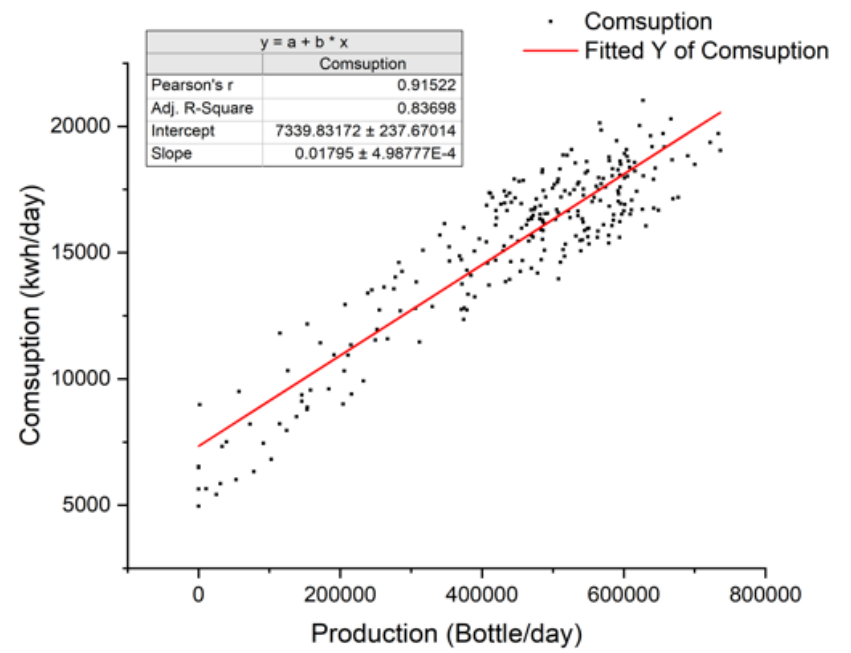

Fig. 5. Baseline of the period analyzed.

Its correlation is greater $\mathrm{R}^{2}=0.8376$, and its adjusted baseline is shown in (5).

$$
E_{t}=0.0179 \cdot P+7339.8
$$

Now, the target line is constructed using the actual consumption data below the baseline of electricity consumption, i.e., the data for which $\mathrm{E}_{\mathrm{t}}-\mathrm{E}_{\text {Real }}>0$. Fig. 6 shows the target line.

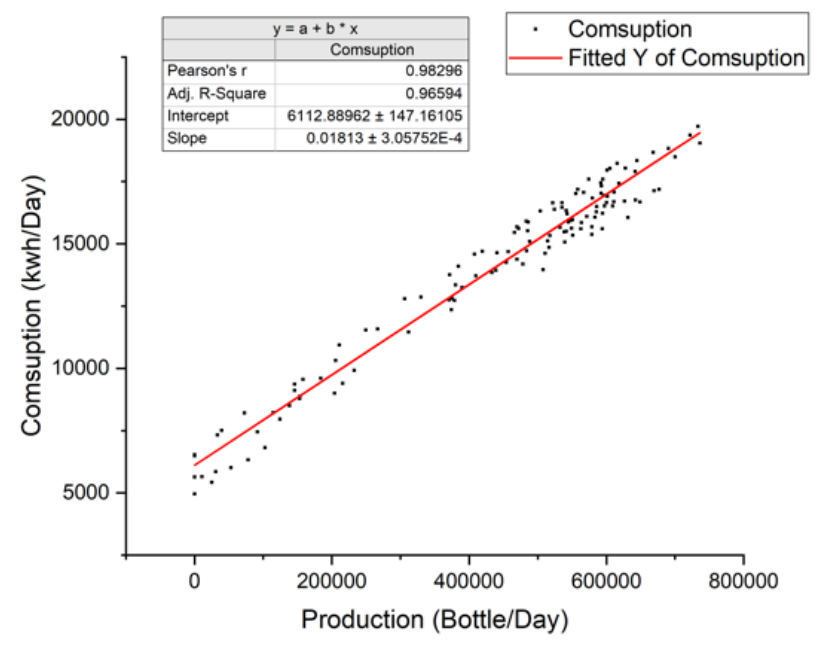

Fig. 6. Target line.

The goal line is presented in (6).

$$
E_{\text {goal }}=0.0181 \cdot P+6112.9
$$

From (5) and (6) corresponding to the baselines and target, respectively, a savings potential is determined, which is related to good manufacturing practices, without the need to make technological changes in the plant, the percentage of savings is given by the ENAP calculated in the adjusted baseline and in the target line as shown in Table IV. 
TABLE IV

COMPARISON BETWEEN BASE LINE AND GOAL LINE

\begin{tabular}{ccc}
\hline \hline Parameter & Value & Unit \\
\hline ENAP baseline & 7339.8 & $\mathrm{kWh} /$ day \\
ENAP goal line & 6112.9 & $\mathrm{kWh} /$ day \\
Potential savings & $8.724 \%$ & $\mathrm{kWh} /$ day \\
\hline \hline
\end{tabular}

The control limits graph helps to visualize the behavior of a variable as a function of certain established limits. Fig. 7 shows the control limits graph.

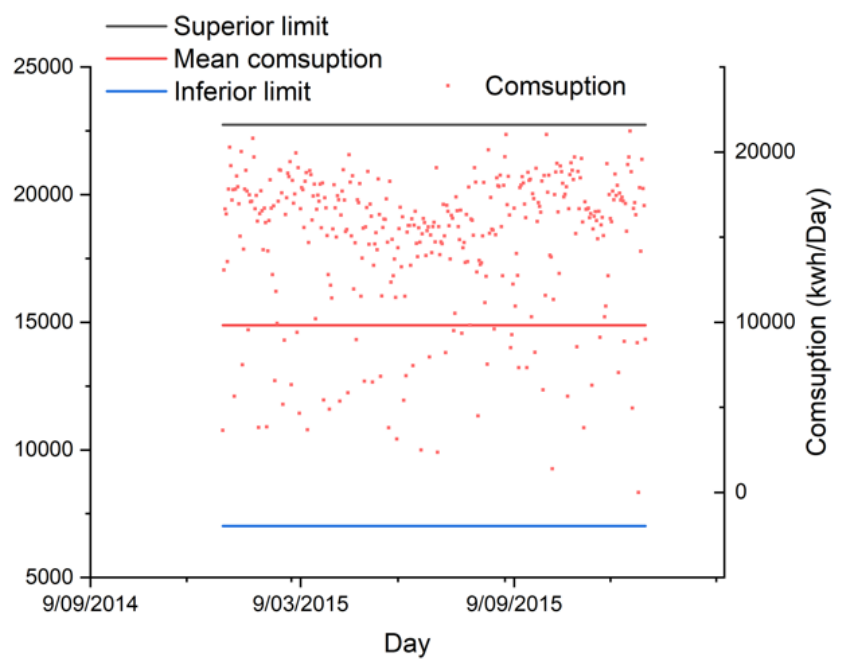

Fig. 7. Control limits graph.

From the graph, some points exceed the upper limit, but some points are below the lower limit. As for not exceeding the upper limit shows that there are no high peaks in energy consumption, so it shows stability in the processes. It helps to identify abnormal patterns, which are seen in some points where consumption was very low or 0 , which can mean a decrease in production or that there was no production that day.

The consumption index is an energy performance indicator that is analyzed by comparing the index of actual consumption with the theoretical, and both are plotted against the production of the plant. The energy consumption index is defined as the relationship between the energy consumed and the value of production obtained through this energy consumed, as shown in (7).

$$
I C_{\text {Real }}=\frac{E_{\text {Real }}}{P}
$$

The theoretical consumption index is estimated, according to (8).

$$
I C_{\text {theoretical }}=\frac{E_{\text {theoretical }}}{P}
$$

The theoretical energy consumption (8) is calculated with (5) of the baseline after data filtering. Replacing (5) in (8) gives (9) to calculate the theoretical consumption index.

$$
I C_{\text {theoretical }}=0.0179+\frac{7339.8}{P}
$$

From the previous analysis, several opportunities for improvement were identified, including the following:

- Reduction of the working pressure of the system, since a high operating pressure contributes to the increase in the probability of leakage and this increases costs because it causes an increase in the power consumed by the air compressor, without increasing the efficiency of production.

- Reducing potential leakage points, while reducing the operating pressure of the system helps to reduce the impact of these does not provide a complete solution, these leakage points can occur anywhere in the system but is more common to occur in the following areas: pipe joints, hoses, quick type connections, maintenance units, condensate drains, valves, thread seals and equipment arranged at the point of use. In this way, it was proposed to reduce the number of connections and splices; this way, the expense would only become labor, in addition to replacing the elements in poor condition.

- Training of personnel, we sought to raise awareness of the staff of the plant on the cost and rational use of compressed air, although it is true that air can be considered a resource of high availability, the action of compressing the air is expensive, to give an idea of the cost generated by a leak, having an orifice of $6 \mathrm{~mm}$ and in a period of 8 hours, would lose 17 USD approximately, for a period of 8000 hours, equivalent to 333 days, the cost of the same leak would be 17000 USD.

\section{CONCLUSION}

After carrying out an exhaustive study within the organization, it is possible to observe the importance of the implementation of an integrated energy system, not only because of what it represents at an economic level but also because it allows compliance with the environmental regulations that govern these organizations, allowing us to follow the sustainable line that has been proposed to follow given the environmental problems in which the planet currently finds itself. This proved to have the potential necessary to obtain certification under the standard ISO 50001.

In the Pareto diagram by the equipment it was seen that $82 \%$ of the energy consumption is associated with six equipment: Bellis Compressor, KHS Blower, SIDEL Blower, Chiller York 70T.R and Sullair L4 Compressor, which also belong to the 3 areas where more electrical energy is consumed, according to the diagram of Pareto by areas, which are: Compressors, Blowers and Peripheral Equipment. The data was filtered to the consumption vs. production graph, to obtain the adjusted 
baseline and then the target line and thus obtain the savings potential, which for the year of analysis was $8.724 \%$.

With the results obtained from the studies, one of the main measures taken was the optimization of compressed air, and an action plan was designed for the air transporter ACMI which sought to reduce potential numbers of leakage, reduce the working pressure of the system and also train personnel, this was hand in hand with other opportunities for improvement related to compressors, which are the maximum consumers of energy in the plant, reducing the working pressure of these and also the demand for compressed air. Other improvement opportunities aimed at other areas were considered in order to optimize the use of energy.

\section{ACKNOWLEDGMENT}

The authors are grateful to the researcher of the Kai research group from the Universidad del Atlántico for his collaboration and technical support received in the logistic required to visit the company.

\section{REFERENCES}

[1] A. McKane et al., "Predicting the quantifiable impacts of ISO 50001 on climate change mitigation," Energy Policy, vol. 107, no. 2017, pp. 278288, Aug 2017, DOI: 10.1016/j.enpol.2017.04.049.

[2] B. Gopalakrishnan, K. Ramamoorthy, E. Crowe, S.Chaudhari, and H. Latif, "A structured approach for facilitating the implementation of ISO 50001 standard in the manufacturing sector," Sustain Energy Technol. Assessments, vol. 7, no. 2014, pp. 154-165, Sep 2014, DOI: 10.1016/j.seta.2014.04.006.

[3] V. António da Silva Gonçalves and F.J. Mil-Homens dos Santos, "Energy management system ISO 50001:2011 and energy management for sustainable development," Energy Policy, vol. 133, no. 2019, pp. 110868, Oct 2019, DOI: 10.1016/j.enpol.2019.07.004.

[4] H.N. Pallares, S.V. Acosta, J.E.D. Forero, and A.R. Montenegro, Implementación de un banco para pruebas en motor Diésel monocilíndrico con aplicaciones investigativas, Scientia et technica, vol. 22, no. 4, pp. 330-340, Dic. 2017, DOI: 10.22517/23447214.16111

[5] J.E.D. Forero, W.G. Estrada, and J.S. Guerrero, Desarrollo de una metodología para la predicción del volumen real en la cámara de combustión de motores diésel utilizando elementos finitos, INGE CUC, vol. 14, no, 1, pp. 122-132, ene. 2018, DOI: 10.17981/ingecuc.14.1.2018.11

[6] E. Jamila and S. Abdelmjid, "Physical Modeling of a Hybrid Wind Turbine-solar Panel System Using Simscape Language," Int. J. Eng., vol. 27, no. 11(B), pp. 1767-1776, Nov 2014, DOI: 10.5829/idosi.ije.2014.27.11b.15.

[7] R. Davarnejad and P. Hosseinitabar, "Application of Iron Electrode in Textile Industry Wastewater Treatment Using Electro-fenton Technique: Experimental and Statistical Study," Int. J. Eng., vol. 29, no. 7, pp. 887897, Jun 2016, DOI: 10.5829/idosi.ije.2016.29.07a.01.

[8] R. Alaei and M. Setak, "Selecting Efficient Service-providers in Electric Power Distribution Industry Using Combinatorial Reverse Auction," Int. J. Eng., vol. 30, no. 9, pp. 1342-1351, Sep 2017, DOI: 10.5829/idosi.ije.2017.30.09c.07.

[9] B. Jovanović and J. Filipović, "ISO 50001 standard-based energy management maturity model - Proposal and validation in industry," $J$. Clean Prod., vol. 112, Part 4, pp. 2744-2755, Jan 2016, DOI: 10.1016/j.jclepro.2015.10.023.

[10] J. C. Campos, E. Lora Figueroa, L. Merino Stand and I. Tovar Ospino, "Sistema de Gestión Integral de la Energía. Guía para la implementación," Universidad del Atlántico, Barranquilla, Atlántico, Colombia. 2007.

[11] J. C. Campos and O. Prias, "Guía implementación SGE según ISO 50001," Universidad Nacional de Bogotá, Bogotá, Cundinamarca,
Colombia. Universidad del Atlántico, Barranquilla, Atlántico, Colombia. 2013.

[12] I. Dzene, I. Polikarpova, L. Zogla and M. Rosa, "Application of ISO 50001 for Implementation of Sustainable Energy Action Plans," Energy Procedia, vol. 72, no. 2015, pp. 111-118, Jun 2015, DOI: 10.1016/j.egypro.2015.06.016.

[13] J. M. Sousa Lira, E. G. Salgado, and L. A. Beijo, "Which factors does the diffusion of ISO 50001 in different regions of the world is influenced?," J. Clean Prod., vol. 226, no. 2019, pp. 759-767, Jul 2019, DOI: 10.1016/j.clepro.2019.04.127.

[14] W. A. Pelser, J. C. Vosloo, and M. J. Mathews, "Results and prospects of applying an ISO 50001 based reporting system on a cement plant,"

J. Clean Prod., vol. 198, no. 2018, pp. 642-653, Oct 2018, DOI: 10.1016/j.clepro.2018.07.071.

[15] A. Kamenders, M. Rosa and K. Kass, "Low carbon municipalities. The impact of energy management on climate mitigation at local scale," Energy Procedia, vol. 128, no. 2017, pp. 172-178, Sep 2017, DOI: 10.1016/j.egypro.2017.09.038.

[16] W. Cai et al., "Promoting sustainability of manufacturing industry through the lean energy-saving and emission-reduction strategy," Sci. Total Environ., vol. 665, no. 2019, pp. 23-32, May 2019, DOI: 10.1016/j.scitotenv.2019.02.069.

[17] O. A. I. Masood, M. I. A. Al-Hady, and A. K. M. Ali, "Applying the Principles of Green Architecture for Saving Energy in Buildings," Energy Procedia, vol. 115, no. 2017, pp. 369-382, Jun 2017, DOI: 10.1016/j.egypro.2017.05.034.

[18] F. Sohrabi, M. Nazari-Heris, B. Mohammadi-Ivatloo, and S. Asadi, "Optimal chiller loading for saving energy by exchange market algorithm," Energy Build, vol. 169, no. 2018, pp. 245-253, Jun 2018, DOI: 10.1016/j.enbuild.2018.03.077.

[19] H. Zhao and B. Lin, "Resources allocation and more efficient use of energy in China's textile industry," Energy, vol. 185, no. 2019, pp. 111-120, Oct 2019, DOI: 10.1016/j.energy.2019.06.173.

[20] C. Gao, W. Gao, K. Song, H. Na, F. Tian and S. Zhang, "Comprehensive evaluation on energy-water saving effects in iron and steel industry,"

Sci. Total Environ., vol. 670, no. 2019, pp. 346-360, Jun 2019, DOI: 10.1016/j.scitotenv.2019.03.101.

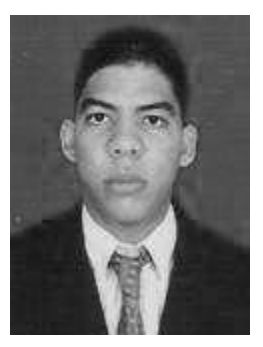

Guillermo Valencia Ochoa, was born in Barranquilla, Atlántico, Colombia, in 1984. $\mathrm{He}$ received the Bs. in Mechanical Engineering from Universidad del Norte, Colombia; Magister in Mechanical Engineering, Energy Conversion Line, Universidad del Norte, Colombia. Ph.D in Engineering, focus on Energy, Thermodynamics, and Environment, from Universidad Pontificia Bolivariana, Colombia. Also, is an assistant professor of the Mechanical Engineering Program, Specialization in Energy Efficient Management, and Master in Energy Management at Universidad del Atlántico.

ORCID: http://orcid.org/0000-0001-5437-1964

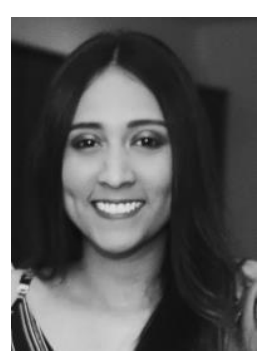

Katherin Rodriguez Rodriguez, was born in Barranquilla, Atlántico, Colombia in 1994. She received a B.S. in Chemical Engineering from the Universidad del Atlántico of Barranquilla, Colombia, in 2018. From 2016 to 2018, she was part of the Universidad del Atlántico Energy Efficiency Research Group. Since 2018 she has been working in the energy sector, implementing energy management systems to industrial companies.

ORCID: https://orcid.org/0000-0001-8278-2584 


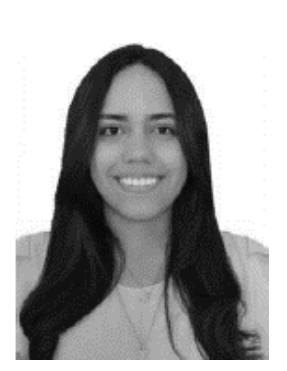

Gloria Torregroza Matos, was born in Montería, Córdoba, Colombia, in 1995. She received a B.S. in Chemical Engineering from the Universidad del Atlántico of Barranquilla, Colombia, in 2018. From 2016 to 2018, she was part of the Universidad del Atlántico Energy Efficiency Research Group. Since 2018 she has been working in the pharmaceutical sector, starting with an internship where she was part of a resources optimization group, including energy optimization.

ORCID: https://orcid.org/0000-0003-4070-9455

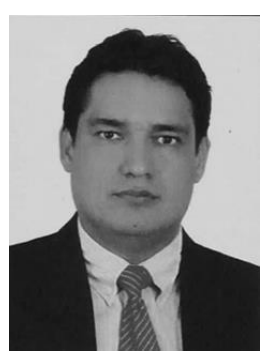

Carlos Acevedo Peñaloza, was born in Montería, Córdoba, Colombia in 1995. He received the Bs. in Mechanical Engineering from Universidad Francisco de Paula Santander-UFPS, located in Cucuta, Colombia, in 1995. Master in Mechanical Engineering from Universidad de los Andes, Bogota, Colombia in 1997. $\mathrm{Ph}$. D in Engineering from the Universidad Politecnica de Cataluna, Barcelona, España in 2005. Hi is currently a full-time professor at the mechanical engineering department of the UFPS.

ORCID: https://orcid.org/0000-0002-5049-8754

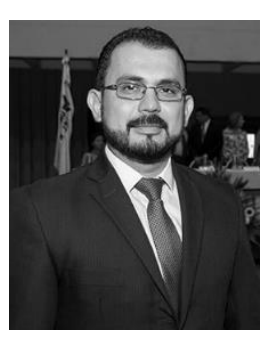

Jorge Duarte Forero, born in Barranquilla, Colombia. Is a full-time professor at the Universidad del Atlántico. Received a degree in Mechanical Engineering from Universidad del Atlántico, located in Barranquilla, Colombia in 2007. Master in Mechanical Engineering from Universidad del Norte, Barranquilla, Colombia, in 2012. Ph. D in Engineering from the Universidad del Norte, Colombia, in 2017. He is an assistant professor of the Mechanical Engineering Program.

ORCID: http://orcid.org/0000-0001-7345-9590 